\title{
Pilot Census of marine life in the Gulf of Maine: contributions of technology
}

\section{Opération pilote du Recensement de la vie marine dans le golfe du Maine : les apports de la technologie}

\author{
Kenneth G. Foote * \\ Woods Hole Oceanographic Institution, Woods Hole, MA, 02543, USA
}

Received 11 June 2002; accepted 2 October 2002

\begin{abstract}
Recent advances in physical oceanography, sampling and observation tools, and data management methods are sufficient to enable a wide range of organisms in the Gulf of Maine to be quantified and related both to other organisms and to the physical habitat. A pilot Census of marine life in the Gulf of Maine would advance the goals of ecosystem understanding and management in a timely manner. A prerequisite is knowledge of the distribution and abundance of the organisms that inhabit, both permanently and transiently, the Gulf of Maine and adjacent waters, namely those of Georges Bank, Browns Bank, and Slope Sea, including the New England seamounts. Both systematic and synoptic investigations of a spectrum of marine life are needed to supplement current data holdings, which, if extensive with respect to fish and certain marine mammals, are sparse with respect to the larger biogeography of the system. Technology offers the means of collecting and organizing such data. Efficiency in collection argues for dividing the spectrum of marine life into a number of functional groups, whose constituent organisms can be observed or sampled by the same or similar techniques. Five groups are identified: offshore subtidal benthos, intertidal and nearshore subtidal benthos, plankton, fish and squid, and large marine animals and seabirds. Associated tools of observation and sampling are listed and illustrated for two categories: high-frequency scientific echo sounders and underwater video microscopes. Parameters of the physical habitat are listed, and the power of the Gulf of Maine Ocean Observing System to define the physical oceanography is noted. Issues of data management, systems, and uses are described. Some benefits of a pilot census are noted. For the scientific community, these include making available biogeographic data that can support the formulation of data-based hypotheses. Testing these in the Gulf of Maine and adjacent waters may enable new knowledge of the particular ecosystem to be extended to distant ecosystems.
\end{abstract}

(C) 2002 Ifremer/CNRS/IRD/Éditions scientifiques et médicales Elsevier SAS. All rights reserved.

\section{Résumé}

Les avancées récentes en océanographie physique, dans les techniques de prélèvement et d'observation et dans le maniement des données suffisent à faciliter la quantification d'une vaste gamme d'organismes dans le golfe du Maine et à mettre en lumière leurs interrelations ainsi que leur liaison avec l'habitat physique. L'opération pilote du Recensement de la vie marine dans le golfe du Maine a comme objectif la compréhension et la gestion durable. Avant cela, il est indispensable de connaître la répartition et l'abondance des organismes qui vivent temporairement ou en permanence dans le golfe du Maine et les aires adjacentes : le Georges Bank, le Browns Bank, la Slope Sea incluant les monts sous-marins de New England. Des recherches systématiques et synoptiques de tout un spectre de la vie marine sont nécessaires pour compléter les données actuelles qui, si elles sont étendues pour les poissons et certains mammifères marins, sont éparses pour ce qui est de la biogéographie à grande échelle de cet écosystème. La technologie permet de collecter et d'organiser de telles données. L'efficacité de cette collecte permet de diviser le spectre de la vie marine en groupes fonctionnels dont les organismes constituants peuvent être observés ou prélevés par les mêmes techniques ou des méthodes similaires. Cinq groupes sont identifiés : le benthos subtidal du large, le benthos côtier et intertidal, le plancton, les poissons et céphalopodes et, enfin, les grands animaux marins et les oiseaux de mer. Les outils permettant observation et prélèvement sont énumérés pour deux catégories : les échosondeurs à haute fréquence et les vidéo-microscopes sous-marins. Les paramètres du milieu physique sont présentés et la puissance du système d'observation du golfe du Maine pour définir ce contexte

\footnotetext{
* Corresponding author.

E-mail address: Kfoote@whoi.edu (K.G. Foote).
} 
physique est évaluée. Les conséquences de la gestion des données, des systèmes et des usages sont décrites. Pour la communauté scientifique, ceci comporte la mise à disposition des données biogéographiques aptes à permettre la formulation d'hypothèses basées sur les données. Les tester dans le golfe du Maine et ses régions adjacentes permettra une connaissance nouvelle d'un écosystème particulier pouvant être étendue à des écosystèmes lointains.

(C) 2002 Ifremer/CNRS/IRD/Éditions scientifiques et médicales Elsevier SAS. Tous droits réservés.

Keywords: Census of marine life; Gulf of Maine; Observation and sampling tools

Mots clés: Recensement de la vie marine; Golfe du Maine; Outils d'échantillonnage et d'observation

\section{Introduction}

The Census of marine life is a global research initiative that aims to answer three questions: what lived in the ocean, what lives in the ocean, and what will live in the ocean? (Ausubel, 1999) [Internet address: http://www.coml.org/]. It is sufficiently young to be in the formative stage where pilot projects may literally demonstrate feasibility and introduce tools and techniques for application elsewhere.

The pilot Census of marine life in the Gulf of Maine, including Georges Bank and Browns Bank, with collateral investigations in the Slope Sea and on some New England seamounts (Fig. 1), is one of a number of proposed pilot projects. As initially conceived, it endeavors to describe the current state of the regional ecosystem. The particular biogeographic ambitions are to describe the distribution, diversity, and abundance of the organisms in the ecosystem and their relationships to each other and to the physical environment.

Importantly, a substantial body of knowledge on the regional ecosystem exists (Bigelow and Schroeder, 1953; Backus, 1987; Sherman et al., 1996; Clark, 1998; Wiebe et al., 2001). Much of recent work has been conducted under

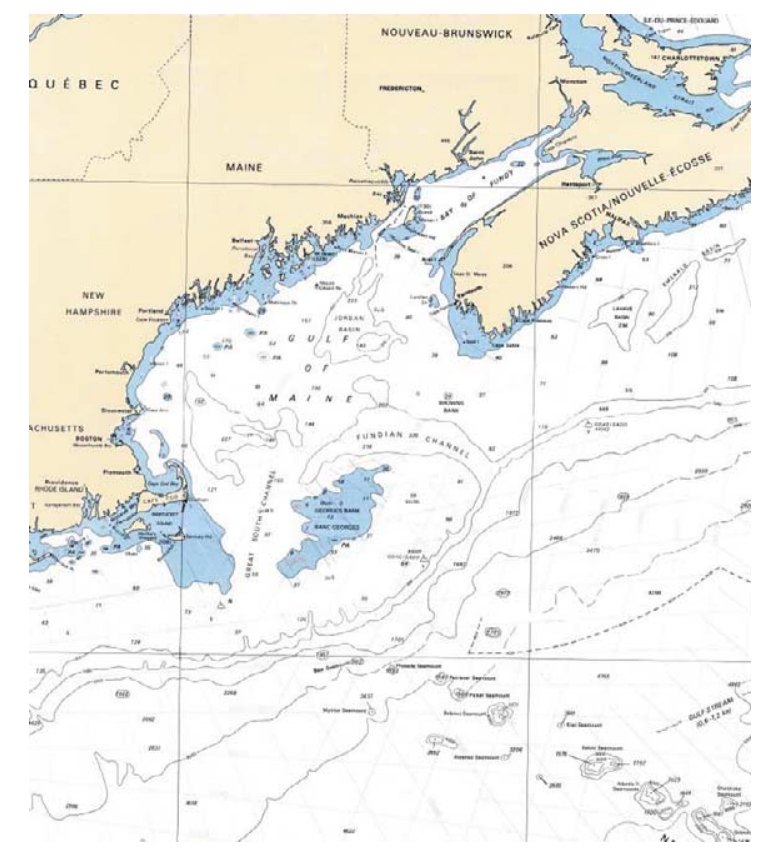

Fig. 1. Map of the study area. the auspices of the US Global Ocean Ecosystem Dynamics (Globec) Northwest Atlantic Georges Bank Program [Internet address: http://globec.whoi.edu/], which has spawned numerous technical reports and scientific papers, whose publication is ongoing.

Findings of the regional US Globec program have been insightful. These must be considered in future efforts to understand the oceanography and biology. Three exemplary findings are summarized.

(1) The inflow of relatively fresh seawater, which is less saline than the deeper oceanic water masses, into the Gulf of Maine through the Northeast Channel is variable both in time and space. In addition to decadal variations (Loder et al., 2001), there are seasonal and interannual variations (Smith et al., 2001). For example, the maximum inflow in spring is shallower than $75 \mathrm{~m}$, but in late summer, it is deeper. The near-surface cross-channel flow from the Scotian Shelf onto Georges Bank is at a maximum in the winter.

(2) Differences in the surface water over the Gulf of Maine are due to differences in phasing of inflow of fresh seawater and runoff from rivers of the western Gulf of Maine watershed (Bisagni et al., 2001). This is manifested by synoptic, high-resolution satellite images of the sea surface temperature over the region.

(3) A coupled nutrient-phytoplankton-zooplankton (NPZ) model and physical oceanographic model with tidal forcing has achieved success in explaining the distribution of microzooplankton on Georges Bank (Franks and Chen, 2001).

These findings and others argue for an examination of the response of biota to changes in the physical oceanography. Conceivably, this can be observed and quantified over rather short periods of time, say of the order of seasons or a few years, given sufficiently synoptic surveys throughout the region. That the spatial distributions of organisms can be predicted on the basis of the evolving oceanography could become the overall working hypothesis. Particular working hypotheses would relate to specific organisms and their habitats, including oceanography.

To achieve the kind of synoptic region-wide surveying that is necessary to characterize the ecosystem, remotesensing tools must be used operationally (Fig. 2) and their data processed with appropriate schemes that include visualization, analysis, and synthesis. Coupled biological and 


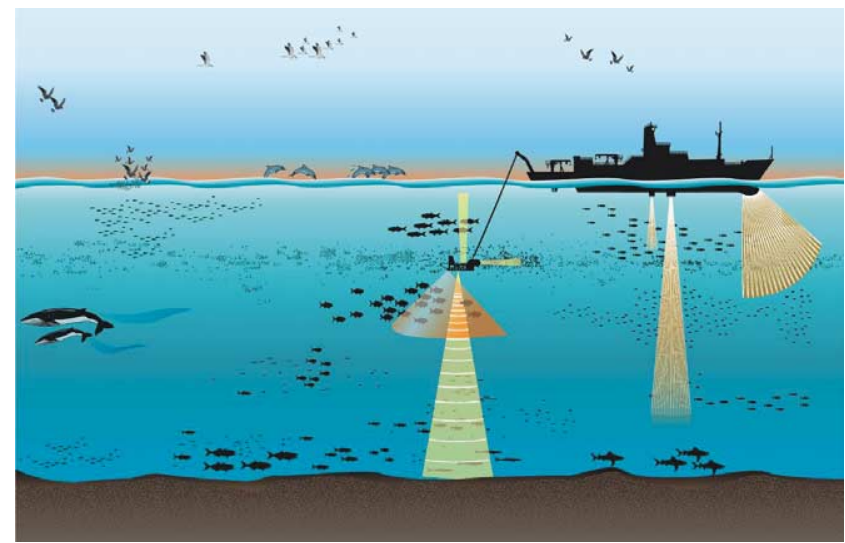

Fig. 2. Conceptual diagram of remote sensing of marine organisms by acoustical and optical means.

physical models need to be developed for higher-level organisms than microzooplankton and for the range of forcing functions. A description of some elements of the pilot census methods follows.

\section{Spectrum of marine life}

In general, attempts to describe an ecosystem through selected subsets of components are futile. Thus, in the pilot census, the spectrum of marine life is considered. For convenience in observation and sampling, the spectrum can reasonably be divided into functional groups, which are listed below.

- Offshore subtidal benthos.

- Intertidal and nearshore subtidal benthos.

- Plankton: viruses, bacteria, protozoa, phytoplankton, zooplankton, ichthyoplankton.

- Fish and squid: demersal, pelagic.

- Large pelagic animals, marine mammals, and seabirds.

\section{Sampling and observation}

A combination of traditional and new, state-of-the-art tools and techniques will be necessary to perform the requisite surveys of the spectrum of marine life. Some generic tools and platforms are indicated.

\subsection{Sampling tools for physical capture}

- Water bottle.

- Pump.

- Gauze recorder.

- Plankton net.

- Bottom trawl.

- Pelagic, or midwater, trawl.

- Gillnet.

- Weir.

- Longline.

- Trap.

- Box corer.

- Dredge.

\subsection{Observational tools for remote sensing}

- Optical particle counter.

- Video microscope.

- Imaging flow cytometer.

- Other video systems.

- Camera.

- Bathyphotometer.

- Acoustics: scientific echo sounder.

- Short-range ultrasonic narrowband.

- Long-range ultrasonic narrowband.

- Composite narrowband and broadband.

Broadband.

- Acoustics: sonar.

- Mechanically scanned beam.

- Electronic sector scanning.

- Multibeam.

- Sidescan.

- Sighting, both shipboard and aerial.

- Tagging.

- Laser line scan.

- Spectrometer.

- Lidar.

\subsection{Platforms}

- Research vessel.

- Fishing vessel.

- Towed vehicle.

- Remotely operated vehicle.

- Autonomous underwater vehicle.

- Vertical profiler.

- Buoy (drifting, moored).

- Ocean bottom system.

- Airplane.

- Satellite.

The tools are described in the scientific literature. Some are in use in regional survey operations, but others await introduction or refinement, as in the case of the flow cytometer and microscope (FLOCAM) (Sieracki et al., 1998) for buoy-installation. Two operational tools with largely untapped potential for surveys in the Gulf of Maine are described.

\subsection{High-frequency scientific echo sounder system}

A scientific echo sounder system generally consists of a transducer, or a device for converting an electrical signal into a pressure wave and vice versa, electronics to control the transmission and reception processes, a display for the echo signal, and often a data management system for datalogging and postprocessing, among other functions. The frequency of a typical high-frequency echo sounder may lie in the range from about 18,000 vibrations per second, or $18 \mathrm{kHz}$, to one million vibrations per second, or $1 \mathrm{MHz}$. The corresponding acoustic wavelengths in water vary from 
about $8.3 \mathrm{~cm}$ at $18 \mathrm{kHz}$ to $1.5 \mathrm{~mm}$ at $1 \mathrm{MHz}$. The significance of the wavelength is that it is a measure of imaging power. If the wavelength is less than typical dimensions of the organism, then the echo will be relatively large compared to that when the wavelength is greater than the same dimensions. Therefore, echoes from fish will potentially be significant at most wavelengths, while those from small zooplankton will be significant only at the shorter wavelengths. Euphausiids, or small shrimp-like creatures also called krill, which are essential ingredients of certain whale diets, may yield relatively powerful echoes at wavelengths shorter than the length of the animal, roughly $2 \mathrm{~cm}$, hence at frequencies greater than about $100 \mathrm{kHz}$. Copepods, with lengths of about $2 \mathrm{~mm}$, are another important food item for some whales, yielding detectable echoes at wavelengths shorter than about $2 \mathrm{~mm}$, hence at frequencies greater than about $1 \mathrm{MHz}$.

There is a difference in the rate of absorption of acoustic energy. Generally, waves of higher frequency are absorbed more rapidly than those of lower frequency. Large single cod, for instance, can be detected at a range of about $500 \mathrm{~m}$ at frequencies less than about $50 \mathrm{kHz}$. At $1 \mathrm{MHz}$, the same animal might be detected at a maximum range of about $25 \mathrm{~m}$.

Scientific echo sounder systems are commercially available, e.g., that described by Bodholt et al. (1989). These are operational and in routine use in other regions, with postprocessing performed by systems such as the Bergen Echo Integrator (Foote et al., 1991), but they are scarcely used in the Gulf of Maine and in any case not for routine stock-assessment purposes. A number of powerful multiplefrequency or broadband echo sounders are in research use, e.g., those described by Austin et al. (1998), Wiebe et al. (2002) and Foote et al. (1999), but again, they have potential operational uses.

\subsection{Video plankton recorder}

The video plankton recorder (VPR) (Davis et al., 1992a, b) is an underwater microscope with a coupled video system that can be towed through the water column to make observations of small organisms. Plankton, such as mesozooplankton, in the approximate size range $0.2-20 \mathrm{~mm}$, can be imaged. These include copepods, which are among the most numerous macroscopic organisms on earth, and other species such as hydroids and medusa. The quality of the images is generally sufficient to distinguish among species, and the same images can be classified automatically, as by a trained neural network, even at a video-image acquisition rate of 60 frames per second $(60 \mathrm{~Hz})$. Such automated classification effects a rapid reduction of a vast quantity of data to figures describing patterns of concentration.

The VPR was developed during the US Globec Georges Bank Regional Program, to which it contributed unique and valuable data about mesozooplankton (Davis et al., 1996; Gallager et al., 1996; Ashjian et al., 2001). It is presently being refined at the Woods Hole Oceanographic Institution for more routine surveying operations.

\section{Physical environment}

The habitat of the organisms is determined both by the physical environment and by the organisms themselves. The physical environment is defined by the bathymetry or bottom topography, hydrography, circulation, and forcing functions, in addition to other factors. Established procedures exist for quantifying the physical environment so that it can be modeled, allowing predictions to be made of the state of the environment when data are lacking. Some quantities to be measured were defined by a working group at the Pilot Marine Census Workshop, May 2000 [Internet addresses: http://www.whoi.edu/gomcensus/ and http://www.whoi.edu/marinecensus/].

\subsection{Geological variables}

- Bathymetry.

- Substrate, including grain size, mineralogy, organic fraction.

- Bedform, both static and dynamic due to both currents and organisms.

- Sea surface temperature (SST).

\subsection{Physical variables especially represented through vertical profiles}

- Temperature.

- Salinity.

- Pressure.

- Density.

- Oxygen concentration.

- Velocity.

- Velocity shear.

- Turbulence.

- Bottom roughness.

- Processes distributed over an area or volume, such as tides, internal waves.

\subsection{Meteorological variables}

- Wind.

- Solar insolation.

- Heat fluxes.

- Air temperature.

- Dew point.

\subsection{Other variables}

- Chlorophyll fluorescence.

- Nutrients: nitrogen, phosphorus, silicon.

- Light profiles.

- Optical properties, both apparent and inherent.

- Satellite-derived ocean color among other properties. 
Significantly, the Gulf of Maine Ocean observing system (GoMOOS) [Internet address: http://www.gomoos.org/] is operational. It provides daily ocean-circulation-model predictions of physical characteristics of the water column (RARGOM workshop, January 2001), i.e., it defines the physical oceanographic state of the Gulf of Maine. This represents an unprecedented achievement and an invaluable resource for the pilot census.

\section{Data}

A number of issues are involved. Some of these are covered by the umbrella of data management, others fall under the categories of systems and uses. Both are described.

\subsection{Data management}

In some projects, data are the end product. In others, they are a means to an end. Both categories apply to the pilot Census of marine life in the Gulf of Maine, where the aim is clear: extraction of scientific information. Since this process is often subjective, involving faculties of analysis, synthesis, and imagination, the data themselves possess a transcendent value. They may provide future researchers with clues or even keys to solutions of ecosystem problems. To serve such a role, however, data must be archived in a retrievable, understandable form, hence the need for data management.

In the long term, the Ocean Biogeographic Information System (OBIS) (Grassle, 2000) [Internet address: http://www.iobis.org/] being developed for the Census of marine life will be a home for pilot census data. It will also provide a convenient framework for their access and retrieval. In fact, the Gulf of Maine is the subject of one of the OBIS projects, namely the Gulf of Maine Biogeographic Information System (GMBIS) (Tsontos and Kiefer, 2000) [Internet address: http://netviewer.usc.edu/web/].

Entry of data into a database implies quality control. This is also required for direct project use of the data. Quality control may be said to begin with the organization of data collection efforts. Calibration is an essential operation for each instrument and technique. Adherence to standard protocols is a valuable safeguard. Visualization, application of statistical tests, and controls on self-consistency, are specific error-checking measures to test the quality of data after their collection.

\subsection{Data systems}

A total of three data systems are envisioned. The primary data on organism distribution and abundance will be stored in a relational database. GMBIS (Tsontos and Kiefer, 2000) will provide the tools for accessing, visualizing, and analyzing these data. Selected synthetic data products derived from the operation of GMBIS on the relational data will be assembled in an electronic data atlas.

\subsection{Data uses}

Using the data to describe the spatial distributions of organisms is straightforward, with many precedents in marine science. Using the data to define relationships of organisms both to other organisms and to the physical environment is, however, less straightforward. Techniques exist for relating individual species or groups of organisms to the physical environment, but are less developed for relating different groups of organisms to themselves. Development of techniques for relating groups of organisms in time and space is vital for understanding predation on the large scale, a governing principle of organism distribution, and hence the ecosystem.

Data on organism distribution and the physical environment, as well as higher-level information on relationships, are expected to be critical in modeling the ecosystem. The influence of fishing as a form of predation also will be incorporated in the ecosystem model.

Quantification of biodiversity may also be pursued within the pilot census, but will require other tools of analysis. Four candidate tools are Classification and regression tree (cart) analysis, generalized additive models (GAMs), power law distributions, and geostatistical variography. Applications of cart analysis abound in studies of land birds, yet despite the similarity of mobile aggregations of species, these are largely unknown techniques in marine ecosystem analyses. The potential of cart and other tools remains a subject of speculation, waiting, perhaps, for the stimulus of the pilot census before introduction into ecosystem studies.

\section{Scientific and societal benefits}

\subsection{Scientific benefits}

A number of scientific benefits may accrue from conducting the census, in addition to potential contributions to the global Census of marine life. In terms of developing methods and collecting data, the benefits include:

- rendering state-of-the-art tools operational for routine survey use,

- extending the working depth of the tools, as through investigations in the Slope water and on the New England seamounts and

- providing reliable numbers for modeling.

Given success in data collection, it will be possible to formulate stronger, data-based hypotheses on the biogeography of the Gulf of Maine ecosystem. Testing these will advance the larger goals of ecosystem understanding and management. 


\subsection{Fishing industry and societal benefits}

Rendering state-of-the-art remote sensing tools operational might be expected to lead to methods that yield information about size and species of observed organisms. Translation of these into simple dedicated devices for use on board fishing vessels may have an immediate and lasting impact on fishing practice, namely institution of pre-capture selectivity by the fisherman.

The consequences of improved ecosystem knowledge are also tangible. Specifically, modeling the ecosystem may render biological oceanography operational. Predictions could thus be made about the evolution of target species under the influence of changes in oceanic climate, human fishing, and possible management actions, inevitably changing and improving the quality of management advice. Fishermen, the fishing industry, resource managers, consumers, the regional economy, and science at large, not to mention the ecosystem itself, will be the direct beneficiaries.

\section{Environmental impact}

The environmental impact of the pilot census will be similar to that of routine oceanographic and fisheries research cruises. With the heavy emphasis on remote sensing tools, performance of the census may eventually lessen the dependence of fisheries research on physical capture for quantification of target species.

\section{Acknowledgements}

J. Doucette is thanked for preparing Fig. 2, originally inspired by a schematic diagram by Y. Simard. C.J. Decker, L.S. Incze, E. Richert are thanked for various comments on the manuscript. Support by the Alfred P. Sloan Foundation is acknowledged. This is Woods Hole Oceanographic Institution contribution no. 10681.

\section{References}

Ashjian, C.J., Davis, C.S., Gallager, S.M., Alatalo, P., 2001. Distribution of plankton, particles, and hydrographic features across Georges Bank described using the Video Plankton Recorder. Deep-Sea Res. II 48, $245-282$.

Austin, T.C., Arthur, R.I., Torkleson, T.C., Wiebe, P.H., Stanton, T.K., 1998. BIOMAPER II: a towed bio-acoustic survey system for zooplankton and fish assessment. Proceedings of the Ocean Community Conference '98. Marine Technology Society, pp. 933-938.

Ausubel, J.H., 1999. Towards a Census of marine life. Oceanography 12 (3), 4-5.

Backus, R.H. (Ed.), 1987. Georges Bank. MIT Press, Cambridge, MA.

Bigelow, H.B., Schroeder, W.C., 1953. Fishes of the Gulf of Maine. Fishery Bulletin of the Fish and Wildlife Service, 53. US Government Printing Office, Washington, DC 577 p.
Bisagni, J.J., Seemann, K.W., Mavor, T.P., 2001. High-resolution satellitederived sea-surface temperature variability over the Gulf of Maine and Georges Bank region, 1993-1996. Deep-Sea Res. II 48, 71-94.

Bodholt, H., Nes, H., Solli, H., 1989. A new echo-sounder system. Proc. Institute of Acoustics 11 (3), 123-130.

Clark, S.H. (Ed.), Status of fishery resources off the northeastern United States for 1998, NOAA Technical Memorandum NMFS-NE-115, 1998.

Davis, C.S., Gallager, S.M., Berman, M.S., Haury, L.R., Strickler, J.R., 1992a. The Video Plankton Recorder (VPR): design and initial result. Archiv fur Hydrobiologie. Beihefte. Ergebnisse der Limnologie 36, $67-81$.

Davis, C.S., Gallager, S.M., Solow, A.R., 1992b. Microaggregations of oceanic plankton observed by towed video microscopy. Science 257 , 230-232.

Davis, C.S., Gallager, S.M., Marra, M., Stewart, W.K., 1996. Rapid visualization of plankton abundance and taxonomic composition using the Video Plankton Recorder (VPR). Deep-Sea Research II, 43, 1947-1970. Archiv fur Hydrobiologie. Beihefte. Ergebnisse der Limnologie 36, 67-81.

Foote, K.G., Knudsen, H.P., Korneliussen, R.J., Nordboe, P.E., Roeang, K., 1991. Postprocessing system for echo sounder data. J. Acoust. Soc. Am. 90, 37-47.

Foote, K.G., Knutsen, T., Atkins, P.R., Bongiovanni, C., Francis, D.T.I., Eriksen, P.K., Mortensen, T., 1999. A seven-octave-bandwidth echo sounding system for application to fish and zooplankton Acustica-acta acustica, 85, S68\&. J. Acoust. Soc. Am. 105, 994.

Franks, P.J.S., Chen, C., 2001. A 3-D prognostic numerical model study of the Georges Bank ecosystem. Part II: biological-physical model. Deep-Sea Res. II 48, 457-482.

Gallager, S.M., Davis, C.S., Epstein, A.W., Solow, A., Beardsley, R.C., 1996. High-resolution observations of plankton spatial distributions correlated with hydrography in the Great South Channel, Georges Bank. Deep-Sea Res. II 43, 1627-1663.

Grassle, J.F., 2000. The Ocean Biogeographic Information System (OBIS): an on-line, worldwide atlas for accessing, modeling and mapping marine biological data in a multidimensional geographic context. Oceanography 13 (3), 5-7.

Loder, J.W., Shore, J.A., Hannah, C.G., Petrie, B.D., 2001. Decadal-scale hydrographic and circulation variability in the Scotia-Maine region. Deep-Sea Res. II 48, 3-35.

Sherman, K., Jaworski, N.A., Smayda, T.J. (Eds.), 1996. The Northeast Shelf Ecosystem: Assessment, Sustainability, and Management. Blackwell Science, Cambridge, MA.

Sieracki, C.K., Sieracki, M.E., Yentsch, C.S., 1998. An imaging-in-flow system for automated analysis of marine microplankton. Mar. Ecol. Prog. Ser. 168, 285-296.

Smith, P.C., Houghton, R.W., Fairbanks, R.G., Mountain, D.G., 2001. Interannual variability of boundary fluxes and water mass properties in the Gulf of Maine and on Georges Bank: 1993-1997. Deep-Sea Res. II 48, 37-70.

Tsontos, V., Kiefer, D.A., 2000. Development of a dynamic biogeographic information system for the Gulf of Maine. Oceanography 13 (3), $25-30$.

Wiebe, P.H., Beardsley, R.C., Bucklin, A.C., Mountain, D.G. Coupled biological and physical studies of plankton populations: Georges Bank and related North Atlantic regions, 2001, Deep-Sea Res. II 48 (1-3), 1-2.

Wiebe, P.H., Stanton, T.K., Greene, C.H., Benfield, M.C., Sosik, H.M., Austin, T., Warren, J.D., Hammar, T., 2002. Biomaper II: an integrated instrument platform for coupled biological and physical measurements in coastal and oceanic regimes. IEEE J. Oceanic Engineering 27 (3). 